\title{
DIGESTIBLE LYSINE LEVELS FOR GROWER PHASE BROWN EGG LAYERS
}

\author{
LEITE, Paulo Ricardo de Sá da Costa ${ }^{1}$; \\ LEANDRO, Nadja Susana Mogyca ${ }^{1}$; \\ STRINGHINI, José Henrique ${ }^{1}$; \\ MELLO, Heloisa Helena de Carvalho ${ }^{1}$; \\ CAFÉ, Marcos Barcellos ${ }^{1}$; \\ OLIVEIRA, Eduardo Miranda de ${ }^{1}$; \\ PEREIRA, Marcela Luzia Rodrigues ${ }^{1}$.
}

\section{ABSTRACT}

$\mathrm{T}$ he objective was to determine the level of digestible lysine in the grower diet of brown egg layers at two weight categories, and assess the residual effect of the grower diet on the laying phase. A total of 400 13-week-old brown egg layers were used, in a randomized blocks design with a $2 \times 4$ factorial arrangement (two weight categories $\mathrm{x}$ four digestible lysine levels: 5.29, 6.29, 7.29 and $8.29 \mathrm{~g} / \mathrm{kg}$ ), with five replications and 10 birds per experimental unit. A metabolism assay was carried out during the $17^{\text {th }}$ week of age. Body weight, feed intake, feed conversion and weight gain were evaluated between 23 and 35 weeks; and egg quality was assessed during three 28-day periods. Data were subjected to analysis of variance and polynomial regression. No link was found between layer weight categories and lysine levels in grower diet for all studied variables. Nitrogen balance increased as digestible lysine was added to diets. There was no effect of digestible lysine on weight gain and precocity of production. Birds in the standard weight category were more precocious and had higher egg production and weight during the laying phase. Digestible lysine levels in diet did not influence performance and egg quality during the laying phase. A level of $5.2 \mathrm{~g} / \mathrm{kg}$ of digestible lysine is recommended in grower diet (13 to 20 weeks of age) for brown egg layers, which corresponds to an intake of $550 \mathrm{mg} / \mathrm{bird} /$ day.

Keywords: Amino acid. Embrapa. Egg. Body weight. 


\section{INTRODUCTION}

Layer egg production depends on how hens are reared since the starter and grower phases. Hens with adequate weight and body composition at the start of the production phase can express their full genetic potential, with superior performance during the laying phase (RIBEIRO et al., 2008; UDEH, 2007).

Grower pullets must ingest nutrients in sufficient amounts to meet nutritional requirements for proper body weight, as they undergo a stage of faster body and reproductive system development. Amino acids are particularly important during this growth stage.

According to Jardim Filho et al. (2011), lysine is related to protein deposition (meat and eggs) and lysine plays an important metabolic function, since its deficiency depresses growth and production. Consequently, supplementation of lysine in diets for poultry is recommended (SANTOS et al.,2014).

The literature varies on the lysine levels recommended for inclusion in the feed of grower hens; also, few works exist on lysine supplementation for regaining body weight in birds that did not reach adequate weight at the start of production. Therefore, it is suggested that higher levels of digestible lysine can lead to greater weight gain for layers and improve egg production.

Body weight at the start of production is important for the laying phase, and lysine is considered to be an amino acid linked to protein synthesis. Thus, the objective was to determine the level of digestible lysine in grower feeds (13 to 20 weeks) for brown egg layers at two weight categories, and assess the residual effect of grower diets on the laying phase.

\section{MATERIAL AND METHODS}

A total of 400 Embrapa 031 lineage brown egg layers were assigned at 13 weeks of age into randomized blocks (with cage level being the block factor), with eight treatments in a $2 \times 4$ factorial arrangement (two weights $x$ four lysine levels), five replications with 10 birds per experimental unit. 
At 13 weeks of age, the hens were divided into two categories according to weight average: lightweight, with $838.23 \mathrm{~g}$; and standard weight (according to the lineage manual), with $1,039 \mathrm{~g}$. The birds were housed in pairs inside divided battery cages $(25 \times 37.5 \times 45 \mathrm{~cm})$. The experimental period lasted between 13 and 35 weeks of age. The experimental diets were provided to the birds during the grower period (13 to 20 weeks of age). After that period, all birds received the same layer diet until 35 weeks of age.

The experimental diets were formulated according to the nutritional requirements proposed by Rostagno et al. (2011), except for digestible lysine levels (Table 1). The nutritional levels of digestible lysine in the diets were obtained from a basal diet in replacement of starch, to meet the following proposed levels: 5.29, 6.29, 7.29 and $8.29 \mathrm{~g} / \mathrm{kg}$ of digestible lysine in diet. The layers received diets with varying levels of digestible lysine only during the recommended grower period (from the $13^{\text {th }}$ to $20^{\text {th }}$ week of age). The layer diet (Table 1) was the same for all birds when the egg production average reached 5\%, and it was formulated according to the nutritional requirements set by Rostagno et al. (2011). 
Table 1 - Composition and nutrients of the experimental diets $\left(\mathrm{g} \mathrm{kg}^{-1}\right.$ as fed).

\begin{tabular}{llc}
\hline Ingredients & Basal diet (Grower) & Layer diet \\
\hline Corn & 663.54 & 637.80 \\
Soybean meal & 120.95 & 157.62 \\
Limestone & 12.33 & 83.30 \\
Wheat Bran & 177.37 & 101.73 \\
Dicalcium Phosphate & 9.84 & 11.21 \\
Starch & 10.0 & ---- \\
Premix ${ }^{1}$ & 3.0 & 3.0 \\
Salt & 2.92 & 4.08 \\
DL-methionine & 0.5 & 1.15 \\
L-lysine- HCL & 0 & 0.16
\end{tabular}

Calculated nutritional composition (g/kg)

Crude protein 140.0

Metabolizable energy (Kcal kg-1)

$2.900 \quad 2.700$

Calcium

Available phosphorus

Digestible lysine

Digestible met + cyst

Digestible methionine

Linoleic acid

Digestible arginine

Sodium

Digestible threonine

\footnotetext{
${ }^{1}$ Mineral and vitamin supplement for layers (composition/kg of product): halquinol 6,666.67 mg; manganese $33,333 \mathrm{mg}$; zinc 26,666.67 mg; iron 16,666.67 mg; copper 2,666.67 mg; iodine $250 \mathrm{mg}$; vitamin A 2,666,667 IU; vitamin E 1,8333.33 mg; ethoxyquin $678.49 \mathrm{mg}$; vitamin D3 600,000 IU; vitamin K3 $400 \mathrm{mg}$; vitamin B1 333.33 mg; vitamin B2 1,000 mg; vitamin B6 566.67 mg; vitamin B12 2,666.67 mcg; niacin 6.000 mg; choline 25.316,67 $\mathrm{mg}$; folic acid $93.33 \mathrm{mg}$; pantothenic acid 2,166.67 mg; selenium $93.33 \mathrm{mg}$.
} 
Weight gain and feed intake were evaluated during the grower phase, and a metabolism assay was carried out when the hens were 17 weeks old, using the method of total excreta collection. For the metabolism assay, 80 birds (two per experimental plot) were taken at random and housed in cages containing collection trays. Feces were collected twice a day during four consecutive days, and then placed in labeled plastic bags, frozen and subjected to bromatological analysis according to the method set by Silva and Queiroz (2009). The data were used to calculate the metabolizability coefficient of fat and determine the nitrogen balance.

When the birds reached average production of $50 \%$, the laying cycle period was initiated to evaluate performance and egg quality data. Three 28-day cycles were considered, corresponding to the period from 23 to 35 weeks. Animal performance and egg quality results were evaluated at the end of each cycle. Zootechnical indexes were: body weight, weight gain, feed intake (g/bird/day), feed conversion ( $\mathrm{kg} / \mathrm{kg}$ and $\mathrm{kg} / \mathrm{egg}$ dozen), egg weight, egg mass and yield, and digestible lysine intake. To evaluate egg quality, four eggs per plot were selected on the last three days of each cycle and weighed to determine the yolk and albumen indexes, Haugh unit and egg components (percentage of yolk, albumen and shell).

The data were subjected to analysis of variance and polynomial regression, using SAS statistics software (2000), at 5\% probability.

\section{RESULTS AND DISCUSSION}

In the period from 13 to 20 weeks of age (Table 2) there was no interaction ( $>0.05$ ) between digestible lysine levels and body weight of hens for weight, weight gain and feed intake. Growing levels of digestible lysine in grower feed did not result ( $p>0.05)$ in additional weight gain for the birds during the grower phase - that is, lightweight birds did not reach the weight recommended by the guidebook for the lineage when fed with growing levels of digestible lysine in grower feed. 
Table 2 - Body weight, feed intake and weight gain of brown egg layers at two weight categories, fed different lysine levels in grower feed, from 13 to 20 weeks.

\begin{tabular}{llll}
\hline Weight $(\mathrm{g})$ & Weight $(\mathrm{g})$ & Feed intake $(\mathrm{g})$ & Weight gain $(\mathrm{g})$ \\
\hline Lightweight & $1.494^{\mathrm{b}}$ & 75.75 & 656.35 \\
Standard & $1.644^{\mathrm{a}}$ & 78.72 & 605.08 \\
\hline Digestible lysine $(\mathrm{g} / \mathrm{kg})$ & & 635.53 \\
\hline 5.29 & 1.555 & 75.26 & 610.13 \\
6.29 & 1.552 & 76.05 & 633.32 \\
7.29 & 1.574 & 78.76 & 643.87 \\
8.29 & 1.595 & 78.87 & \\
\hline P-value & & & 0.266 \\
\hline weight & 0.0007 & 0.438 & 0.958 \\
lysine & 0.88 & 0.867 & 0.681 \\
weight x lysine & 0.732 & 0.800 & 18.79 \\
\hline CV (\%) & 8.14 & 11.84 & \\
\hline
\end{tabular}

Means followed by different letters in the same column differ from one another according to the f-test.

There was no effect ( $p>0.05)$ of body weight on feed intake and weight gain. With regard to digestible lysine levels in feed, there was no effect on feed intake results. Likewise, increasing digestible lysine levels in grower feed (13 to 20 weeks of age) did not lead to greater weight gain in birds. The difference in body weight between lightweight and standard weight hens was noticeable from the start of the experimental period (13 weeks) until laying began, on the $20^{\text {th }}$ week of age.

It is suggested that digestible lysine levels in the grower feed did not restore body weight in underweight hens; however, protein levels in the experimental feeds was $14(\mathrm{~g} / \mathrm{kg})$, which may have been low and therefore compromised protein synthesis for weight recovery, as crude protein levels in feed can influence weight gain (BARROS et al., 2006). Neto et al., (2008) verified that Lohmann Brown layers showed greater weight gain when fed grower feed (13 to 18 weeks) with $16 \%$ crude protein. 
There was no interaction ( $p>0.05$ ) between weight and digestible lysine levels for nitrogen intake and excretion, nitrogen balance and metabolizability coefficient of fat, for layers at 17 weeks of age (Table 3).

There was an influence $(p<0.05)$ of bird weight on nitrogen intake, excretion and balance, with greater nitrogen intake seen in standard weight hens compared to lightweight birds. Birds with lower body weight had higher nitrogen retention, but were unable to regain body weight.

Table 3 - Values of nitrogen intake (NI), nitrogen excretion (NE), nitrogen balance (NB) and coefficient of metabolizability of ether extract (CMEE) for brown egg layers at 17 weeks of age, fed various levels of digestible

\begin{tabular}{lllll}
\hline \multicolumn{5}{c}{ lysine in grower feed. } \\
\hline Lightweight & $\mathrm{NI}(\mathrm{g})^{1}$ & $\mathrm{NE}(\mathrm{g})$ & $\mathrm{NB}(\mathrm{g})^{2}$ & CMEE (\%) \\
Standard & $9.56^{\mathrm{b}}$ & $7.36^{\mathrm{b}}$ & $2.20^{\mathrm{a}}$ & 76.86 \\
\hline Digestible lysine (g/kg) & $10.47^{\mathrm{a}}$ & $8.81^{\mathrm{a}}$ & $1.76^{\mathrm{b}}$ & 74.09 \\
5.29 & 8.19 & 7.23 & & \\
6.29 & 9.92 & 7.94 & 0.96 & 76.12 \\
7.29 & 10.48 & 8.45 & 1.98 & 73.81 \\
8.29 & 11.47 & 8.71 & 2.24 & 76.60 \\
\hline & & & 2.75 & 75.37 \\
\hline weight & 0.021 & 0.003 & & \\
lysine & 0.0001 & 0.126 & 0.031 & 0.197 \\
weight x lysine & 0.648 & 0.163 & 0.0001 & 0.798 \\
regression & 0.010 & 0.126 & 0.138 & 0.410 \\
\hline CV (\%) & 11.90 & 17.87 & 0.026 & 0.365 \\
\hline
\end{tabular}

Means followed by different letters in the same column differ from one another according to the f-test.

${ }^{1}$ lightweight: $y=2.8438+9.08 x, R^{2}=0.44$ and standard weight: $y=1.8249+11.69 x, R^{2}=0.67$

${ }^{2}$ lightweight: $y=-2.219336+6.7222354 x-38.21573 x^{2} R^{2}=0.61$; standard weight: $y=-1.364181+4.1918367 x$, $R^{2}=0.64$.

With regard to nitrogen balance (g), the study detected a quadratic effect for lightweight birds and a positive linear effect for standard weight birds. These results suggest that birds 
with different weights respond differently to the nitrogen balance of the diet - standard weight birds showed better use of lysine with higher levels, which may be related to higher maintenance requirements or superior weight gain.

No effect $(p>0.05)$ of digestible lysine was observed on nitrogen excretion and metabolizability coefficient of fat. Conversely, there was a positive linear regression effect on nitrogen intake for birds from both studied categories (Table 3). As digestible lysine levels increased, more nitrogen was retained (NB), showing improved balance between amino acids in diet when lysine levels increased, therefore featuring higher protein synthesis and lower nitrogen excretion. According to Jardim Filho et al. (2011) the lysine levels did not influence protein and energy intake, nitrogen balance or crude fat.

Nitrogen balance was positive for grower brown egg layers, as birds experience growth during this stage and make better use of nitrogen in the diet.

There was no effect ( $p>0.05$ ) of categories weight and digestible lysine levels in grower diet over age at first egg and $50 \%$ egg production (Table 4$)$. An effect $(p<0.05)$ of bird weight was observed on age at first egg; standard weight hens were more precocious compared to lightweight birds. The same behavior was observed for $50 \%$ production, in which heavier hens reached that yield at 152 days of age, whereas lightweight birds reached it at 156 days. 
Table 4 - Age at first egg (days) and 50\% production (days) for brown egg layers at two weight categories fed various levels of digestible lysine in grower feed.

\begin{tabular}{lll}
\hline Weight & First egg & $50 \%$ production \\
\hline Lightweight & $139^{\mathrm{a}}$ & $156^{\mathrm{a}}$ \\
Standard & $127^{\mathrm{b}}$ & $152^{\mathrm{b}}$ \\
\hline \multicolumn{1}{c}{ Digestible lysine $(\mathrm{g} / \mathrm{kg})$} & \\
\hline 5.29 & 131 & 154 \\
6.29 & 132 & 154 \\
7.29 & 131 & 153 \\
8.29 & 138 & 154 \\
\hline P-value & & \\
\hline weight & 0.0001 & 0.023 \\
lysine & 0.409 & 0.954 \\
weight x lysine & 0.501 & 0.723 \\
\hline CV (\%) & 6.55 & 3.65 \\
\hline
\end{tabular}

Means followed by different letters in the same column differ from one another according to the f-test.

There was no effect $(p>0.05)$ of the different digestible lysine levels on age at first egg and $50 \%$ production. Results agree with those by Jardim Filho et al. (2011) who found no effects on the lysine levels age at first egg and $50 \%$ egg production.

There was no effect ( $p>0.05$ ) of weight category and digestible lysine levels on zootechnical performance of birds in the period from 23 to 35 weeks of age (Table 5). No influence of bird weight was observed on feed conversion $(\mathrm{kg} / \mathrm{kg}$ and $\mathrm{kg} / \mathrm{dz})$. Bird weight did influence $(p<0.05)$ weight gain ( 23 to 35 weeks) and feed intake. Lightweight layers had greater weight gain compared to standard weight birds, whereas feed intake was greater for standard weight birds. These results are in agreement with Lacin et al. (2008), who detected higher feed intake for heavier Lohmann birds (1.814 g) as compared to lighter hens (1.585 g) during the starter phase. 
Table 5 - Feed intake (FI), feed conversion (FC) and weight gain (WG) for laying hens from 23 to 35 weeks of age, fed various levels of digestible lysine during the grower phase.

\begin{tabular}{|c|c|c|c|c|c|}
\hline Weight & $\begin{array}{l}\text { Bird weight } \\
\text { (g) }\end{array}$ & $\begin{array}{l}\text { FI } \\
\text { (g/bird/day) }\end{array}$ & $\begin{array}{l}\mathrm{FC} \\
(\mathrm{kg} / \mathrm{kg})\end{array}$ & $\mathrm{FC}(\mathrm{kg} / \mathrm{dz})$ & WG (g) \\
\hline \multirow[t]{2}{*}{ Lightweight } & $1.569^{b}$ & $97.88^{b}$ & 2.347 & 1.521 & 731.26 \\
\hline & & & & & a \\
\hline \multirow[t]{2}{*}{ Standard } & $1.674^{a}$ & $104.87^{\mathrm{a}}$ & 2.329 & 1.552 & 635.11 \\
\hline & & & & & b \\
\hline \multicolumn{6}{|c|}{ Digestible lysine $(\mathrm{g} / \mathrm{kg})$} \\
\hline 5.29 & 1.607 & 104.06 & 2.422 & 1.583 & 687.79 \\
\hline 6.29 & 1.612 & 100.20 & 2.307 & 1.520 & 669.41 \\
\hline 7.29 & 1.619 & 101.54 & 2.319 & 1.544 & 678.02 \\
\hline 8.29 & 1.648 & 99.69 & 2.304 & 1.500 & 697.52 \\
\hline \multicolumn{6}{|l|}{ P-value } \\
\hline weight & 0.0001 & 0.014 & 0.807 & 0.526 & 0.0001 \\
\hline lysine & 0.141 & 0.667 & 0.626 & 0.644 & 0.546 \\
\hline weight $\mathrm{x}$ lysine & 0.464 & 0.218 & 0.619 & 0.715 & 0.362 \\
\hline CV (\%) & 2.58 & 8.39 & 9.60 & 9.42 & 6.57 \\
\hline
\end{tabular}

Means followed by different letters in the same column differ from one another according to the f-test.

No effect $(p>0.05)$ of digestible lysine levels in grower feed was observed on data for feed conversion and weight gain of layers. Higher lysine levels in grower feed did not add body weight in underweight layers - that is, body weight was not regained, which likely resulted in lower egg yield.

There was no interaction $(p>0.05)$ between the factors under study for the results of egg weight, yield and mass. There was no effect of digestible lysine in grower feed on egg weight, yield percentage and egg mass (Table 6). Higher egg weight and mass $(p<0.05)$ were observed in the heavier group, which is in agreement with the results obtained by Udeh (2007) and Lacin et al. (2008). 
Table 6 - Egg weight, egg yield and egg mass for laying hens at 23 to 35 weeks of age, fed various levels of digestible lysine during the grower phase.

\begin{tabular}{llll}
\hline Weight & Egg weight (g) & Egg yield (\%) & Egg mass (g/bird/day) \\
\hline Lightweight & $54.32^{\mathrm{b}}$ & $76.21^{\mathrm{b}}$ & $40.26^{\mathrm{b}}$ \\
Standard & $55.89^{\mathrm{a}}$ & $79.76^{\mathrm{a}}$ & $42.57^{\mathrm{a}}$ \\
\hline \multicolumn{2}{l}{ Digestible lysine (g/kg) } & & \\
\hline 5.29 & 54.98 & 77.03 & 41.04 \\
6.29 & 55.39 & 78.58 & 41.48 \\
7.29 & 55.6 & 77.53 & 41.64 \\
8.29 & 54.38 & 78.81 & 41.51 \\
\hline \multicolumn{1}{c}{ P-value } & & & \\
\hline weight & 0.0007 & 0.007 & 0.005 \\
lysine & 0.280 & 0.736 & 0.953 \\
weight x lysine & 0.250 & 0.517 & 0.197 \\
\hline CV (\%) & 2.44 & 5.09 & 5.93 \\
\hline
\end{tabular}

Means followed by different letters in the same column differ from one another according to the f-test.

Higher egg weight for heavier birds as observed in this study is in agreement with the literature (ALKAN et al., 2010; HAQ et al., 2011). In the present study it was observed that the egg weight is directly related to body weight and sexual maturity, and birds that lay smaller eggs at the start of production will continuously produce smaller eggs.

A higher egg yield percentage $(p<0.05)$ can be observed for standard weight layers when compared to lightweight birds. Akbas and Takma (2005) mentioned that body weight is positively related to egg production. However, Lacin et al. (2008) did not observe higher egg yield for heavier Lohmann layers (over $1.600 \mathrm{~g}$ ) when compared to birds with lower body weight $(1,400-1,500 \mathrm{~g})$ in the period from 24 to 40 weeks of age.

There was no interaction ( $p>0.05$ ) between weight and digestible lysine levels in grower feed for the variables of egg components and quality (Table 7). 
Table 7 - Albumen percentage, yolk percentage, albumen index (Al), yolk index ( $\mathrm{Yl}$ ) and Haugh unit (HU) of eggs from laying hens between 23 and 35 weeks of age, fed digestible lysine levels during the grower phase.

\begin{tabular}{llllll}
\hline Weight & Albumen (\%) & Yolk (\%) & Al & Yl & HU \\
\hline Lightweight & 65.79 & 23.86 & 0.162 & 0.466 & 99.80 \\
Standard & 65.80 & 23.90 & 0.163 & 0.472 & 100.85 \\
\hline Digestible lysine (g/kg) & & & & & \\
\hline 5.29 & 65.97 & 23.86 & 0.168 & 0.468 & 101.19 \\
6.29 & 65.83 & 23.81 & 0.163 & 0.468 & 100.23 \\
7.29 & 65.80 & 23.77 & 0.160 & 0.475 & 99.77 \\
8.29 & 65.59 & 24.10 & 0.160 & 0.465 & 100.11 \\
\hline P-value & & & & & \\
\hline Weight & 0.953 & 0.824 & 0.883 & 0.145 & 0.088 \\
lysine & 0.708 & 0.569 & 0.291 & 0.371 & 0.420 \\
weight x lysine & 0.106 & 0.212 & 0.867 & 0.080 & 0.985 \\
\hline CV (\%) & 1.08 & 2.39 & 6.60 & 2.72 & 1.90 \\
\hline
\end{tabular}

Means followed by different letters in the same column differ from one another according to the f-test.

Layer weight did not have an effect on the percentage of egg components (albumen and yolk), indexes (yolk and albumen) and Haugh unit of eggs from brown egg layers fed various levels of digestible lysine in grower feed. Kirikc et al. (2007) and Lacin et al. (2008) observed higher Haugh unit values for lightweight birds when compared to birds with greater body weight.

Digestible lysine levels in grower diet did not influence $(p>0.05)$ the percentages of egg components (albumen and yolk), albumen and yolk indexes and Haugh unit (Table 7). These results are in agreement with those presented by Pastore et al. (2016), Santos et al. (2014), Figueiredo et al. (2012) and Jardim Filho et al. (2010). Nevertheless, lysine is an essential amino acid in the structure of egg components. Kakhki and Zarghi (2016) detected significant improvement in egg production, egg weight, egg mass, Haugh unit with an increase in lysine intake. 
There was no interaction ( $p>0.05$ ) between layer body weight and level of digestible lysine for the results of shell weight and thickness and specific density of eggs (Table 8).

No effect was observed ( $p>0.05$ ) of bird weight on the specific density of eggs (Table 8 ). There was an effect $(p<0.05)$ of body weight on shell percentage and thickness. Standard weight layers showed lower shell percentage and thickness when compared to lightweight layers. This result may be linked to the higher egg weight for standard weight layers - that is, egg weight is one of the factors that most impact shell quality, as heavier eggs tend to have thinner shells given that birds are unable to deposit calcium at the same rate for egg growth and weight. Digestible lysine levels in grower diet did not influence $(p>0.05)$ the percentages shell, shell thickness and specific density. Results agree with those by Kakhki and Zarghi (2016), which found that dietary lysine concentration did not have a significant impact on percentage of egg components, specific gravity and egg shell thickness.

Table 8 - Shell percentages, shell thickness and specific density of eggs from laying hens between 23 and 35 weeks of age, fed various levels of digestible lysine during the grower phase.

\begin{tabular}{llll}
\hline Weight & Shell (\%) & Shell thickness $(\mathrm{mm})$ & Specific density $\left(\mathrm{g} \mathrm{cm}^{-3}\right)$ \\
\hline Lightweight & $10.51^{\mathrm{a}}$ & $0.41^{\mathrm{a}}$ & 1.098 \\
Standard & $10.32^{\mathrm{b}}$ & $0.40^{\mathrm{b}}$ & 1.098 \\
\hline \multicolumn{1}{c}{ Digestible lysine $(\mathrm{g} / \mathrm{kg})$} & & 1.098 \\
\hline 5.29 & 10.39 & 0.41 & 1.098 \\
6.29 & 10.46 & 0.41 & 1.098 \\
7.29 & 10.39 & 0.41 & 1.098 \\
8.29 & 10.40 & 0.41 & \\
\hline P-value & & & 0.642 \\
\hline weight & 0.043 & 0.034 & 0.844 \\
lysine & 0.943 & 0.839 & 0.278 \\
weight x lysine & 0.323 & 0.457 & 0.09 \\
\hline CV (\%) & 2.71 & 2.79 & \\
\hline
\end{tabular}

Means followed by different letters in the same column differ from one another according to the f-test (5\%). 
The results suggest that hen weight during the grower phase can influence egg product and weight during the laying phase. However, growing levels of digestible lysine in feed were not sufficient to improve the body weight of underweight birds; perhaps body weight recovery should be undertaken during the first weeks of age, during the starter phase. Moreover, the level of crude protein in the diet may influence weight recovery for lightweight hens.

\section{CONCLUSION}

The results of this study recommend $5.29 \mathrm{~g} / \mathrm{kg}$ of digestible lysine in grower feed (13 to 20 weeks of age) for brown egg layers of the Embrapa 031 lineage, which corresponds to an intake of $550 \mathrm{mg} / \mathrm{bird} /$ day.

\section{NÍVEIS DE LISINA DIGESTÍVEL PARA POEDEIRAS SEMIPESADAS}

\section{RESUMO}

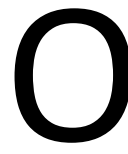

bjetivou-se determinar a exigência nutricional de lisina digestível na dieta de recria de frangas semipesadas com duas categorias de peso. Foram utilizadas 400 poedeiras semipesadas com 13 semanas de idade, distribuídas em delineamento em blocos ao acaso em esquema fatorial $2 \times 4$ (duas categorias de peso $\times$ quatro níveis de lisina digestível, 5,29; 6,29; 7,29 e 8,29 g/kg), com cinco repetições e 10 aves por unidade experimental. Na 17a semana de idade foi realizado um ensaio metabólico e no período de 23 a 35 semanas foram avaliados o peso corporal, consumo de ração, conversão alimentar e ganho de peso e a qualidade de ovos durante três períodos de 28 dias. Os dados foram submetidos à análise de variância e a regressão polinomial. Não houve interação entre as categorias de peso da franga e níveis de lisina na dieta de recria para todas as variáveis estudadas. $O$ balanço de nitrogênio aumentou com o acréscimo de lisina digestível na dieta. Não houve efeito da lisina digestível sobre o ganho de peso, precocidade na produção e aves na categoria peso padrão foram mais precoces e apresentaram maior produção e peso dos ovos na fase de postura. Níveis de lisina digestível na dieta não influenciaram o desempenho e a qualidade de ovos na fase de postura. Recomenda-se o nível de 5,2 g/kg de lisina digestível na dieta de recria (13 a 20 semanas de idade) para poedeiras semipesadas, o que corresponde ao consumo de $550 \mathrm{mg} / \mathrm{ave} / \mathrm{dia}$.

Palavras-chave: Aminoácido. Embrapa. Ovo. Peso Corporal. 


\section{NIVELES DE LISINA DIGESTIBLES PARA PONEDORAS SEMIPESADAS}

\section{RESUMEN}

$\mathrm{E}$ objetivo fue determinar el nivel de lisina digestible en la alimentación de gallinas ponedoras en dos categorías de peso, y evaluar el efecto residual de la dieta del productor, en la fase de puesta. Unas 400 gallinas ponedoras, de huevo marrón, de 13 semanas de edad, dispuestas en un diseño de bloques aleatorios en una disposición factorial de 2 × 4 (dos categorías de peso x cuatro niveles de lisina digestible: 5,29, 6,29, 7,29 y 8,29 $\mathrm{g} / \mathrm{kg}$ ), con cinco repeticiones y 10 aves por unidad experimental, fueron utilizadas. Se realizó un ensayo de metabolismo durante la semana 17 de edad. El peso corporal, la ingesta de alimento, la conversión alimenticia y el aumento de peso se evaluaron en el período entre 23 y 35 semanas. Los datos fueron sometidos al análisis de varianza y la regresión polinomial. No se encontró ningún enlace entre las categorías de peso de capa y los niveles de lisina en la alimentación para todas las variables estudiadas. No hubo efecto de la lisina digestible sobre el aumento de peso y la precocidad de la producción. Los niveles de lisina digestible en la alimentación no influyeron en el rendimiento y la calidad del huevo durante la fase de puesta. Se recomienda un nivel de 5,2 g/kg de lisina digestible en la alimentación del productor (13 a 20 semanas de edad) para las gallinas ponedoras de huevo marrón, lo que corresponde a una ingesta de $550 \mathrm{mg} / \mathrm{ave} /$ día.

Palabras clave: Aminoácido. Embrapa. Huevo. Peso Corporal.

\section{REFERENCES}

AKBAS, Y.; TAKMA, Ç. Canonical correlation analysis for studying the relationship between egg production traits and body weight, egg weight and age at sexual maturity in layers.

Czech Journal of Animal Science, v. 50, n. 4, p. 163-168, 2005.

ALKAN, S.; KARABAĞ, K.; GALIÇ, A.; et al. Effects of selection for body weight and egg production on egg quality traits in japanese quails (Coturnix japonica) of different lines and relationships between these traits. Kafkas Universitesi Veteriner Fakultesi Dergisi, v. 16, n. 2, p. 239-244, 2010. doi: http://dx.doi.org/ 10.9775/kvfd.2009.633

BARROS, L. R.; COSTA, F. G. P.; COSTA, J. S.; et al. Níveis de proteína para frangas semipesadas no período de uma a dezoito semanas de idade. Ciência Animal Brasileira, v. 7, n. 2, p. 131-141, 2006.

FIGUEIREDO, G. O.; BERTECHINI, A. G.; FASSANI, E. J.; et al. Performance and egg quality of laying hens fed with dietary levels of digestible lysine and threonine. Arquivo Brasileiro de Medicina Veterinária e Zootecnia, v. 64, n. 3, p. 743-750, 2012. 
HAQ, R.; HAQ, E.; KHAN, M. F. Correlation between body weight egg \& weight of dokki and fayoumi hen in Pakistan. Journal of Basic and Applied Sciences, v. 7, n. 2, p. 165-168, 2011.

JARDIM FILHO, R. M.; STRINGHNI, J. H.; ANDRADE, M. A.; et al. Níveis de lisina digestível para poedeiras Hy-Line W-36 em produção. Revista Brasileira de Zootecnia, v. 39, n. 4, p. 787795, 2010.

JARDIM FILHO, R. M.; STRINGHINI, J. H.; CAFÉ, M. B. Níveis de lisina digestível para poedeiras Lohmann LSL na fase de 16 a 25 semanas de idade. Revista Brasileira de Zootecnia, v. 40, n. 9, p. 1947-1954, 2011.

KAKHKI, R. A. M.; A. ZARGHI, G. H. Effect of dietary digestible lysine concentration on performance, egg quality, and blood metabolites in laying hens. Journal Applied Poultry Researh, v. 25, p. 506-517, 2016. doi: http://dx.doi.org/10.3382/japr/pfw032

KIRIKC, K.; GUNLU, A.; ÇETIN, O.; et al. Effect of hen weight on egg production and some egg quality characteristics in the Partridge (Alectoris graeca). Poultry Science, v. 86, n. 7, p. 1380-1383, 2007. doi: http://dx.doi.org/10.1093/ps/86.7.1380

LACIN, E.; YILDIZ, A.; ESENBUGA, N.; et al. Effects of differences in the initial body weight of groups on laying performance and egg quality parameters of Lohmann laying hens. Czech Journal of Animal Science, v. 53, n. 11, p. 466-471, 2008.

NETO, R. C. L.; COSTA, F. G. P.; SILVA, J. H. V.; et al. Níveis de proteína bruta e de energia metabolizável para frangas de postura semipesadas de 1 a 18 semanas de idade. Ciência Agrotécnica, v. 32, n. 1, p. 258-266, 2008. doi: http://dx.doi.org/10.1590/S141370542008000100037

PASTORE, S. M.; ALBINO, L. F. T.; GOMES, P. C.; et al. Relação treonina: lisina digestíveis na dieta de poedeiras leves de 42 a 58 semanas de idade. Revista Brasileira de Saúde e Produção Animal, v. 17, n. 3, p. 438-447, 2016.

RIBEIRO, P. A. P.; ROCHA, J. S. R.; LARA, L. J. C.; et al. Pontos críticos no manejo de cria e recria de poedeiras vermelhas. In: CURSO DE ATUALIZAÇÃO EM AVICULTURA PARA POSTURA COMERCIAL, 5, 2008, Jaboticabal. ANAIS. Jaboticabal: UNESP, 2008. P. 69-87.

ROSTAGNO, H. S.; ALBINO, L. F. T.; DONZELLE, J. F.; et al. Tabelas brasileiras para aves e suínos. Composição de alimentos e exigências nutricionais. 3. ed. Viçosa: UFV, 2011. 186p.

SANTOS, T. A.; GERALDO, A.; MACHADO, L. C. Digestible lysine levels for laying hens and their effects on egg quality. Acta Scientiarum, v. 36, n. 1, p. 41-47, 2014. doi: 10.4025/actascianimsci.v36i1.21823

SILVA, D. J.; QUEIROZ, A. C. Análise de Alimentos (métodos químicos e biológicos). 3.ed. Viçosa: Universidade Federal de Viçosa, 2009. 235p. 
UDEH, I. Influence of weight grouping on the short term egg production of two strains of layer type chicken. Animal Research International, v. 4, n. 3, p. 741-744, 2007. doi: http://dx.doi.org/10.4314/ari.v4i3.48684 